\title{
Entrepreneurial Learning by Community-Based Participation through Optimization of Local Potential Development in Karawang
}

\author{
Dayat Hidayat \\ Nonformal Education Department \\ Faculty of Teachers' Training and Education, University of Singaperbangsa Karawang \\ Jl. HS. Ronggowaluyo, East Telukjambe, Karawang 41361, Indonesia \\ dayathidayat194@yahoo.com
}

\begin{abstract}
The essence of lifelong learning community considers that has the same right and opportunities to meet the needs of learning. Entrepreneurial learning aims to improve people's economic empowerment through the analysis of learning needs and the potential of social capital, superiorily and have local wisdom. This study analyzes: 1) entrepreneurial learning process based on community participation, and 2) optimizing the development of local potential. This study used literature analysis method, by doing a comparative study of various sources and conducted in-depth analysis that found a conclusion that can be justified scientifically. The study concluded several findings: First, 1) the process of entrepreneurial learning through community participation includes a) planning, b) implementation, and c) assessment, which involves the participation of the community in identifying learning needs, learning resources, as well as factors supporting and inhibiting the development of local potential, 2) optimization of the local potential development underlying entrepreneurial learning achievement based community participation in the form of energy, thoughts and other material and nonmaterial.
\end{abstract}

Keywords-Participatory learning, based entrepreneurship, local potential.

\section{INTRODUCTION}

Participatory learning process is essentially rooted in a tradition that has grown in the community for generations. These activities are also rooted in the traditions and customs prevailing in the society. Religious values, traditions, and customs that grow and develop in society are potential sources for the development process of participatory learning activities. Traditions and customs that are embraced and respected by the community can give positive values to the development process of participatory learning activities. Motivation was directed so that people can recognize, describe and formulate their potential, then develop the potential of it and turn it to be used for the benefit and common progress. Developing countries remind the business application of positive values that grow in the community to develop participatory learning activities. Participatory learning process is conducted through recycling activities as follows: a reflection-action-and back reflection (reflection-action-and further reflection). An evaluation results indicate that the effects of participatory learning activities have grown sensitive community (responsive) to the reality of life and capable of improving the environment, including improving the economy of the community through community empowerment.

Community empowerment and participation in the development paradigm is a strategy that relies on people (people centered development). This strategy realizes the importance of the capacity of communities to improve the self-reliance and internal strength, through the ability to conduct internal control over the resources of material and non-material significance through the redistribution of capital or ownership (Korten, 1992) in Adimiharja K. and Hikmat, H. (2004: 1)

Sudjana, D. (2007) in Kartika I.A.F. (2011:11-12) suggests that participatory learning is based on the following principles: 1. Based on the needs of learning (learning needs based). Sources of information about the learning needs is actual or potential participant. This need can be identified from the institution or organization that gives a task to the participants who become service target of the institution or organization in which participants work or receive tasks.

2. Goal-oriented learning activities (learning goals and objectives oriented). The objective of learning was prepared by learning resources and participants, taking into account the participants experiences, potentials and available resources in their living environment as well as possible obstacles that arise in the learning activities.

3. Based on the participants (participant centered). Participants included and must play an important role in the planning, implementation and evaluation.

4. Learning from experience (experiential learning). Participatory learning process is developed and implemented by departing from the things that have been learned in the form of knowledge, values and skills of the trainee as well as participants experience, both from experience in the tasks of daily work and also real experience can be implemented to task or learners' job.

From these principles it is showed that there is community involvement as learners in planning (participatory planning), participation in implementation (participatory implementation), and participation in evaluation (participatory evaluation). Participatory learning is a way in which to increase cooperation and participation in decision- 
making. This approach has been applied in the development of training and development planning team. participatory can be the basis for development of learner interaction with the environment to strengthen the duties and functions of the organization (Sumpeno, W. 2009:124).

The learning process is a community-based entrepreneurship consisting of planning, implementation, and assessment that involve the community. Utility planning of a community-based entrepreneurial learning, they are: (1) the learning need to do together in the group that organized and managed by the learners in the community, (2) The program of community assistance is a progressive increase in the learning process is more reliant on components companion in seeking changes in the behavior of citizens for learning, (3) learning activity assistance for community has more orientation to learning objectives that can be used by the learners to improve standard of living and develop participation in business that represent the public interest. (4) The assistance activity focuses on available resources in the community both human resources, as well as the natural to have mutual advantages between learners and their environment. (5) Activity mentoring has more attention in terms of lerners humanity to appreciate the potential and capabilities as well as the emphasis on business to harness the potential and to display the ability in performing activities of thinking and doing in order to achieve the learning objectives that belongs to them in organizing of community-based participatory in entrepreneurial learning. (Sudjana, D. 2004: 144). In the planning stage entrepreneurial community-based learning is conducted by coaching process familiarity, identification of learning needs, learning resources and possible barriers to learning, learning objectives formulation and preparation of learning programs. (Sudjana, D. 2004).

The education program has provided plenty of space for educational institutions to create and manage curriculum that meets the potential and competency of its territory or the environment. This opportunity should be used by the community and local government to create an educational institution that is more targeted, qualified and skilled. Education that can improve the quality of human resources to manage resources or local potential is education that was developed based on local potential.

Optimizing the utilization of local potential that regard to natural resources and the environment (human resources, natural resources, cultural resources, and technological resources) is very supportive on the locally based entrepreneurship training. Local potency study provides an overview of the wisdom traditions of the community in the utilization of natural resources and social wisely to ensure the balance of the environment. This implies that people are required to have the capability in terms of utilizing available local resources. It can be conducted by keeping the balance of the environment, so that environmental sustainability can be maintained. Local potential can be a force that gives authority to the community members to utilize in their lives.

The increase of public in economics for the economic independence of learners, is the expected impact after participating in a community-based entrepreneurial learning. The expected impact follows the process of community-based entrepreneurial learning to match the capacities and potential of local learners. The independence of a change in the standard of living marked by the acquisition of job opportunities or entrepreneurship, acquisition or improvement of income, health and personal appearance.

Entrepreneurial learning strategy through communitybased participatory is entrepreneurial develpment that has a basis of local potential which emphasizes the promotion of economic growth driven by rlearners in utilizing local potentials for development in an effort to improve the economic well-being of local communities. Lincolin, A., Elan, D. et al, (2011:95) argues that this entrepreneurial development strategy that uses a territorial approach that relies primarily on the needs, potential, and local actors of a certain area (locality).

\section{ENTERPRISE LEARNING THROUGH COMMUNITY PARTICIPATION}

The planning stage of enterprise learning through community participation is structured to: (1) help learners prospective to diagnose learning needs to be achieved. Event identification of learning needs was thoroughly committed in the exercise of learning to improve knowledge, attitude and skills of community entrepreneurship. Learner's involvement in the identification activities of learning needs, sources and possible barriers to learning will be implemented into a single entity in the implementation of entrepreneurial learning based on community based participation. At this stage, people learn to help in setting the learning goals. The purpose of learning is based on three reasons. First, it is to provide direction and learning activities. Second, is as the basis for the implementation of learning and the provision of appropriate learning elements. Third, is as a benchmark in evaluating the learning activities are carried out. Hereinafter jointly engage learners prioritize learning objectives to be achieved by the problem, the support and resistance provided or to be provided. Community involvement in formulating the learning objectives was carried out to determine the components of learning, such as learners, learning resources, learning materials, implementation of the learning process, evaluation tools, facilities, tool, and cost. In determining learning needs, the learners' experience factor can be a source social, culture, human resources and natural resources which is very important to note. In designing stage, learning experiences have helped people to apply the principles of organizing learning materials and determine the learning model that will be pursued. (2) help communities prepare study groups. A good situation to involve learners in planning the learning activities is when the revision was carried out on a limited group. Lessons will take place effectively and efficiently if the number of members of the group is not too large. The group members can be mutually giving the learning one another, so that each can be a learning resource for the study of learning materials implemented. Study groups in the implementation of learning contain four characteristics, namely their togetherness needs and motivations, reactions and different skills, organizational 
structure, and group norms (Sudjana, D, 2004: 136). (3) Make entrepreneurial learning program (to prepare and establish) learning materials, methods, techniques, time, evaluation tools and learning facilities.

Community-based entrepreneurial learning is a learning process for learners to acquire functional skills that are useful to enhance the living standard, especially the economy. Participatory learning is interpreted as an effort of learning resources to engage learners in the learning activities. The participation of the learners is realized in three phases namely program planning, implementation of the program and program evaluation of learning activities (Sudjana, D. 2004: 129).

At this stage of the implementation of a community-based entrepreneurial learning: (1) Creating a learning situation by creating an open relationship, intimate and targeted. (2) the interaction of learners, learning resources and administrators PKBM are conducted by horizontal relationships (parallel communication). (3) The learning activities with more emphasis on leraners' activity and learning participation . (4) The approach of learning centered on learners in the preparation of learning materials. Learning activities developed jointly between learners and learning resources. The role of learning resources to help learners in learning activities.

At the stage of the implementation of community-based entrepreneurial learning, the role of the organizer is: (1) to put themselves in positions that are not all-knowing, but use the principle of mutual learning, (2) to help learners in fulfilling their learning activities based on learning needs, essential or urged by learners, (3) to give the motivation to learners to participate in drawing up the learning objectives, learning materials and steps to be taken in learning activities (4) to put themselves as learners to learn from each other in learning activities. (5) together with the learners to perform mutual learning, ie exchanging ideas about the content, processes and outcomes of learning activities as well as on how the ways and steps of developing a learning experience to the next period, (6) to help learners to create a situation of learning activities conducively, develop the spirit of learning and mutual exchange of ideas, (7) to develop learning activities in groups and pay attention to individual interests, helping learners to optimize the response to stimuli that encountered in learning activities, (8) to encourage the learners to improve the spirit of achievement, which is always wishes for a most successful, the spirit of competition, keep away from challenges, and oriented towards a better life in the future, (9) to encourage and help learners to develop problem solving skills based on the life of learners so that they are able to think and take action in real life.

The method in a community-based entrepreneurial learning is an activity or a common way of classifying students in learning activities. Learning techniques are steps or specific ways used by educators in each method of learning, organized and well thought of to achieve a purpose. The methods and techniques used in community-based entrepreneurial learning can be classified as follows: (1) individual learning methods, techniques used: tutorials, individual counseling, individualized learning, apprenticeships and so forth. (2) Method of group learning, a technique used: discussions, simulations, group work, problem solving, role playing, and so forth. (3) Mass learning methods, techniques used: social contacts, social coercion, demonstrations, acts of participation and so forth. (Sudjana, D. 2004: 169-170).

The involvement of learning resources in creating a situation of a community-based entrepreneurial learning are as follows: (1) Helping people learn to create a climate of learning to organize entrepreneurial learning. In the efforts to create a climate of learning, the learning resources together with the learners prepare learning materials, determine the facilities and equipment as well as fostering intimacy between the learners. (2) Helping people learn to perform learning steps. The spelling out of the classification of learning activities into a sequence of steps and learning activities will determine the manner of election techniques appropriate learning and determination of appropriate learning materials to achieve learning objectives. The techniques of learning activities that can be used is participatory techniques in large groups include frequently asked questions, forums, audiences, groups of viewers, reading groups, groups of buzz, the role of listener, the expanded panel, tapping and discussion in the group is limited.

The assessment of learning is important to do to know the success of entrepreneurial learning. Assessment is conducted to collect, process and present data or information that can be used as an input in decision-making (Sudjana, D. 2004:130). Entrepreneurial learning assessment was conducted jointly between the learners and administrators of Community Learning Center (CLC). Through this assessment of entrepreneurial learning, learners determine the extent of the changes that have been experienced and achieved by them through learning activities. The achievement of learning goals will affect people to learn in two respects. First, they have a view on the level of ability that has been achieved through learning activities. Secondly, they are expected to make a new behavior. It becomes current level of ability that will be developed later in order to achieve a better one. Assessment of effect of learning activities includes interrelated of three aspects . First, changes in the standard of living of graduates in the aspect of employment, income, health, and others. Second, efforts to give learning to others in acquisition of learning that has been perceived of its benefits. Third, the participation of learners or graduates in community development activities.

The purpose of community-based entrepreneurial learning is to 1) establish or develop a business unit / incubator deploying and institutional strengthening as a pilot center for the entrepreneurial community in accordance with its potential, 2) create the opportunities for the source of institution funding from earnings of business units / developed business incubator and 3) improve entrepreneurial literacy learners by enhancing the knowledge, attitudes, skills and enterprise independently as an individual or part of a business incubator developed by the institute. (Suryono, Y. And Sumarno, 2013: 7).

Community participatory-based of entrepreneurial learning is implemented by using a curriculum that refers to the standard of entrepreneurial competencies that have been assigned to: 1) identify the types of businesses which are likely 
to be developed in accordance with the environmental conditions and market, 2) write and communicate design of developed business, 3) masteri production skills based on developed business 4) market business products , 5) perform the calculation analysis of profit / loss, 6) establish partnerships, and 7) maintain both literacy and develop competence in running the business. (Suryono, Y. And Sumarno, 2013: 7).

\section{OPTIMIZING THE DEVELOPMENT OF LOCAL POTENTIAL IN COMMUNITY PARTICIPATORY-BASED ENTREPRENEURIAL LEARNING}

Local potential has meaning as a source / power possessed by each region to be utilized in certain activities. Local potential can not be separated from the concept of environmental input as a support for the learning process. By utilizing the existing potential in the community, the community is expected not to feel foreign, so the motivation to develop learning programs can be enhanced.

Factually, it's seen from the lack of real benefits for an area that has a lot of natural productive potential to improve the welfare of the community. And we all know that Indonesia has a wide variety of cultural and natural resources, which could be developed and maintained to enhance community welfare.

The core of local potency is the resource in a certain regions, that is the local potential of the resources that exist in a particular region (Geertz Clifford, 1983:31 in Sudjana, D, 2004). As is the local potential in this study consist of : (1) the type of available local potential (human resources, nature, culture, technology, market, financial institutions, and partnerships) and (2) the utilization of the local potential include: local potential use in learning and how to accumulate the local potential. Local potentials are all kinds of resources that exist in a community environment, which give the benefit in rising of living standards. Local potentials are dominant factors or potentials found in a particular area that is not or less owned by other regions.

Local potential is input from society in organizing non formal education, especially training in entrepreneurship based on local potential. Sudjana, D. (2004: 33) argues that the local potential in the form of local resources is an environmental input to be considered in the implementation of non formal education when it is viewed by a systems approach. Environmental potential is the potential of local resources which has contributed to the ongoing process of entrepreneurial training based on local potential.

Local potential in locally - based entrepreneurship training is also related to the utilization of social and cultural capital. Putnam, et al, in Suharto, E. (2005) social capital is the appearance of social organization, such as trust, norms (or reciprocity), and the network (from the bonds of society), which can improve the efficiency of society by facilitating the coordination and cooperation for mutual benefit. Fukuyama, F. (1995) stated that social capital is a capability that arises from the lack of trust in a community.
Cultural capital is a locally potential-grown from wisdom traditions which is possessed by society as part of their culture. Cultural diversity in the community, can be a potential that can be extracted for using in entrepreneurial training activities based on local potential. The local culture can be used as the basis for entrepreneurial training, so that local people know their own cultural roots to develop the community's economy.

In developing local potential as an environmental input in the implementation of non formal education, including entrepreneurship training based on local potential, Sudjana, D. (2004: 35) suggests several approaches that can be used is: "humanitarian approach, collaborative, participatory, sustainable, and culture ".

The humanitarian approach means that people learn as subjects in the study, so as to have the opportunity to develop its local potential. Learner is no longer looked as an individual who do not know and has not skill, but learner has the ability to be further developed. Collaborative and participative approach which are related to partnership in developing local potential should be carried out among the various parties concerned. Harmonious partnership for mutual support in the utilization of local potential to support the implementation of entrepreneurship training. Sustainable approach. Through this approach, it is hoped all the potentials continuously extracted, so that maximum utilization can be used based on the need. Cultural approach implies that the development of society adapted to the cultural values and traditions prevailing in the society as a potential environment.

Local potential is a local resource that can be seen as an investment to obtain new resources in the community. Therefore local potential is believed to be one of the main components in moving together, the mobility of ideas, mutual trust and mutual benefit to achieve common progress. Local potential plays a very important to the functioning and strengthening of community life. People who have high local potential will open up the possibility of resolving the complexity of building society more easily. The principle of mutual trust, tolerance, and cooperation developed in the community can build a network both within and with other community groups.

People who have high local potential has characteristics as follows: 1) local knowledge is Unwritten. It is known through the oral traditions, 2) local knowledge is communally and Collectively owned, 3) it is closely associated with the elements of nature, 4) it is universal in principle, 5) local knowledge dynamic and systematic, 6) it is simple and understood through the common sense, 7) it is Considered as a common heritage of humanity (Victorino in Sudjana, D. 2004: 37).

From the above opinion it can be explained that potential of local communities have characteristics as follows: 1) local potentials that exist in a community environment, they are not written. This means that the local potential that exists in society is not formed in writing, but people feel its existence, 2) they feel that local potential. It means that people find it to be an integral part of the environment in which they live. A sense of belonging makes people able to exploit local potential with full responsibility, 3) local potential deeply united with nature. This 
means that the local potential possessed by certain areas cannot be separated from the natural environment. Referring to the opinion of Sudjana, D. (2000: 34-35), natural resources include biological resources (biotic) and non-living resources (abiotic), and artificial resources. Namely biological resources of flora and fauna, non-biological resources, namely soil, water, air, energy, minerals. Artificial resources, namely natural resources that have been processed by the human resources for the benefit of life such as, dams, roads, markets, educational institutions and settlements, 4) has a universal nature. This means that every area in principle has the local potential in general, which is composed of human resources, natural resources, and culture, but in the reality of each region has a uniqueness of its local potential, 5) is more practical. This means that the local potential is more practical that can be perceived by the public to be used in life, 6) easily understood by using common sense. This means that the various types of local potential provided easily understood existence, so that everyone can feel its existence without scientific research, 7) is inherited from generation to generation. This means that local potential can be felt by the community for generations by the civilization of mankind.

Therefore, the local potential is a necessary condition for human development, economic, social, political and democratic stability. Various problems and irregularities that occurred in many countries is the main determinant of small local potential to grow in the community. Weak local potential will weaken the spirit of mutual cooperation, exacerbate poverty, increase unemployment, crime, and deter any attempt to improve the welfare of society.

Sudjana, D. (2004: 34) states that the use of natural resources and the environment is very helpful in the learning process. These sources include: 1) human resource, 2) natural resources, 3) cultural resources, and 4) technological resources. Human resources are important assets to take advantage of other resources in the learning activities, including the development of an entrepreneurial society. Human resources becomes a major supporting factor that can affect the learning process to the maximum so as to improve the welfare of the community.

Natural resources consist of biological resources (biotic) and non-living (abiotic), as well as artificial resources. Biological resources include flora and fauna. Non-biological resources include land, water, air, energy, minerals (Sudjana, D. 2004:34-35). The artificial resources include natural resources that have been processed by the human resources for the benefit of life such as, dams, roads, markets, education, and residential homes. Natural resources can be utilized in community entrepreneurship development activities through entrepreneurship training based on local potential. Identifying the needs of potential natural resources need to be excavated society to be utilized as much as possible without interfering with the natural preservation.

Each region has a different local resources, the resources developed should have a comparative advantage of the area compared to other areas. Djojonegoro in Sudjana, D. (2004: 39) argues that the reason for the development of local resources that have comparative advantages is that specialization and more efficient in its development.

Cultural resources are all systems of values and norms that held societies, including the man's work for the benefit of society itself. Local cultural capital contributes significantly to the improvement of local potential resources in improving the welfare of the community. Technological resources are related to the tools and systems that can be used by the people in accordance with their needs. In the selection and use of technology, both the tools and appropriate learning system is expected to facilitate the learning process.

BPPLSP of Regional II Jayagiri Bandung (2004) developed on the type of local resources, namely: "1) nature potential, 2) human potential, 3) cultural potential, 4) the technological potential, 5) market potential, 6) potential in financial institutions, 7) potential partnerships". Sources of natural resources that concern the geographical conditions can be utilized in accordance with the development of human culture. For example, the use of agricultural land and agricultural technologies that have the potential to increase agricultural productivity.

Human resources are the main resources in processing and controlling resources or other potential, so its presence could be balanced, increaseg, got higher quality and more optimized. Human resources that related to the knowledge, attitudes, and skills appropriate, adequate, and continuously developed to empower communities. The cultural resources is the noble cultural values can make a positive contribution in the development of an entrepreneurial society, such as discipline, mutual help, and never give up.

Marketing resource is the product which is devoted most in demand or consume. For example, is a job that corresponds to that required by the institution or a local company, or a type of business that has a high purchasing power of the local community. Potential financial institutions closely associated with the funding or capitalization of the type of business that occupied, for example, the empowerment of banks and cooperatives. Potential partnership is a system of alliances between one and parties or another institution that has mutual benefit. The existence of this potential will affect the smooth operating results.

\section{CONCLUSION}

The steps in participatory training is at the planning stage of learning resources with learners to identify learning needs that will be met through learning activities. Learning resources help learners to identify the source of the necessary resources, learning materials, aids, and other related information. This effort can boost the confidence of the learners and the skills they possess. During the implementation phase, learning resources motivated learners when it is known that the activities and progress of learning was still low. Learning resources help people learn to pay attention to the linkages between the experiences that has been owned by the interests of the other study. Learning resources responded seductively to the efforts of the learners applied the experience and skills they have and help them to use these responses to a similar stimulus from others in real-life situations. Learning resources 
encourage learners to seek and find their own alternative answer to the problems that arise even though the problem was easy to obtain learning resources. While at the stage of assessment, learning resources can motivate learners to evaluate the experience, especially the skills that have been possessed in the work activity or in their life.

People who have high social capital tend to be more efficient and effective in promoting the welfare and life. Optimizing the development of local potential can raise the awareness of individuals about the many opportunities that can be developed for the benefit of society. In the context of human development, the local potential has a great influence because several dimensions of human development is strongly influenced by social capital, among others the ability to solve complexity problems together, encouraging rapid changes in society, raise collective consciousness to improve the quality of life and looking for opportunities that can be utilized for the welfare of society. However, the quality of the individual in society will boost the quality of life which means human development is in parallel with social development.

\section{REFERENCES}

[1] Adimiharja, K. dan Hikmat, H, Participatory Research Appraisal dalam Pelaksanaan Pengabdian kepada Masyarakat, Bandung, Humaniora Utama Press, 2004.

[2] BPPLSP, Program Pendidikan Nonformal dan Informal, Bandung, BPPLSP of Regional II Jayagiri Bandung, 2004.

[3] Fukuyama, F, Trust: The Social Virtues and the Creation of Prosperity, London, Hamish Hamilton, 1995.

[4] Kartika, I.A.F, Mengelola Pelatihan Partisipatif, Bandung, Alfabeta, 2011.

[5] Lincolin, A. and S., Elan, Strategi Pembangunan Perdesaan Berbasis Lokal, Yogyakarta, UPP STIM YKPN, 2011.

[6] Putnam, R.D, The Prosperous Community: Social Capital and Public Life, The American Prospect. Vol. 4, no. 13, 1993.

[7] Sudjana, D, Manajemen Program Pendidikan, untuk Pendidikan Nonformal, dan Pengembangan Sumber Daya Manusia, Bandung, Falah Production, 2004.

[8] Sudjana, D, Pendidikan Nonformal, Wawasan, Sejarah Perkembangan, Falsafah, Teori Pendukung, Azas, Bandung, Falah Production, 2004.

[9] Sudjana, D, Strategi Pembelajaran. Bandung, Falah Production, 2007.

[10] Sudjana, D, Metode dan Teknik Pembelajaran Partisipasif, Bandung, Falah Production, 2004.

[11] Suharto, E, Membangun Masyarakat Memberdayakan Rakyat: Kajian Strategis Pembangunan Kesejahteraan Sosial dan Pekerjaan Sosial, Bandung, Refika Aditama, 2005.

[12] Sumpeno, W, Sekolah Masyarakat, Yogyakarta, Pustaka Pelajar, 2009.

[13] Suryono Y, dan Sumarno, Pembelajaran Kewirausahaan Masyarakat, Yogyakarta, Aditya Media, 2013. 